\title{
Natural HPV immunity and vaccination strategies
}

\author{
Peter L. Stern ${ }^{\mathrm{a}, *}$, Michael Brown ${ }^{\mathrm{b}}$, Simon N. Stacey ${ }^{\mathrm{b}}$, Henry C. Kitchener ${ }^{\mathrm{d}}$, \\ Ian Hampson d, El-Said Abdel-Hady ${ }^{\mathrm{c}, \mathrm{d}}$, Jim V. Moore ${ }^{\mathrm{d}}$ \\ a Department of Immunology, Paterson Institute for Cancer Research, Christie Hospital NHS Trust, Manchester M20 4BX, UK \\ b Department of Molecular Biology, Paterson Institute for Cancer Research, Christie Hospital NHS Trust, \\ Manchester M20 4BX, UK \\ ${ }^{\mathrm{c}}$ Department of Experimental Radiation Oncology, Paterson Institute for Cancer Research, Christie Hospital NHS Trust, \\ Manchester M20 4BX, UK \\ d Academic Department of Obstetrics and Gynaecology and Reproductive Health Care, University of Manchester, \\ St Mary's Hospital, Manchester M13 OJH, UK
}

Received 15 March 2000; accepted 17 March 2000

\begin{abstract}
Background: the task of preventing premature death in women may be delivered by vaccinating against the high-risk papillomaviruses associated with various malignancies. Objectives: we will discuss the immune mechanisms likely to be relevant to the control of an HPV infection in the cervix and assess the limited evidence for such immune recognition in the natural history of infection. Conclusion: the next generation of vaccination strategies should include the use of HPV 16 early (E2 and/or E6 and/or E7) and late gene targets (L1 and L2) expressed as VLPs with their clinical and immunological evaluation aimed at therapy as well as prophylaxis. Important clinical efficacy assessment may be deliverable in relatively short-term studies by targeting patients with HPV 16 associated vulval intraepithelial neoplasia. (C) 2000 Elsevier Science B.V. All rights reserved.
\end{abstract}

Keywords: Human papillomavirus (HPV); Vaccines; Prophylaxis and therapy; Vulval intraepithelial neoplasia

\section{Introduction}

Infection of the cervix with HPV, particularly types 16 and 18, is causally related to the development of cervical cancer via in situ stages (CIN13). However, in immunocompetent individuals, the infection is normally asymptomatic and cleared. Even in cases where infection has led to

\footnotetext{
* Corresponding author. Tel.: + 44-161-4463127; fax: + 44161-4463109.
}

dysplasia, the lesions often regress, especially in the cases of mild dysplasia and in young individuals (Syrjanen, 1996; Duggan et al., 1998). Viral persistence on the other hand is associated with the progression of the lesions (graded CIN1-3 in increasing severity) which may develop to invasive cervical cancer (Ho et al., 1995; Remmink et al., 1995). The viral infection is a necessary but not sufficient component for malignancy. Why most individuals apparently clear the virus while some fail is not known but the increase in frequency of 
HPV lesions in immunosuppressed individuals suggests that the immune system is involved (Petry et al., 1994). This, and the use of several animal papillomavirus models have provided the impetus for the development of vaccination against HPV viral proteins to prevent or treat cervical cancer (reviewed Duggan-Keen et al., 1998; Tindle, 1999). Historically, successful vaccination strategies for key viral diseases have utilised attenuated viruses which effectively mimic a natural infection process and thereby recapitulate the generation of natural immunity. Such vaccination strategies limit the consequences of any infection but are unlikely to completely prevent infection (sterilising immunity). With human papillomavirus only sub-unit immunisation is possible because of the difficulty in propogating the viruses ex vivo as well as safety issues associated with use of inactivated viral vaccines. Although there are some useful precedents from animal models and strong theoretical momentum for the various HPV vaccines in development, it remains the case that the precise viral targets, key serological and/or cell mediated immune effectors and kinetics of the natural immune response controlling HPV infections have not been identified.

\section{Defence mechanisms: theory}

There are two main arms to the immune response which may play a role in the natural clearance of HPV infection, innate and adaptive immunity. Innate immunity consists of a rapidly induced, non-specific response which does not result in immune memory. The innate immune system is localised at epithelial borders and is delivered via several immunomodulatory cytokines and cellular effectors including monocytes, macrophages, NK and antigen presenting cells (APC). The innate immune system is likely to play an important first line of defence in the control of papillomavirus infections. It is triggered by evidence of cellular distress (for example from a bacterial or viral infection) and leads to the destruction of the affected cells and the pathogen. The adaptive immune response arises from a breach of the innate immune response resulting in the generation of antigen specific effector cells and their products that specifically target the pathogen or pathogen infected cell, as well as memory cells that will prevent or limit subsequent infection with the same organism. It is now believed that activation of the innate immune system can act to stimulate the adaptive immune responses.

There are two theories, Self-Non-Self (Janeway, 1992; Medzhitov and Janeway, 1997) and the Danger Model (Matzinger, 1994, 1998) which attempt to understand this. The important difference between these is how they view the initiation of the immune response. The first depends on the concept of recognition of foreignness. Thus the non-self hypothesis is based on a mechanism which utilises germline encoded receptors which recognise pathogen associated molecular patterns (PAMPs), e.g. LPS in gram negative bacteria and dsRNA in RNA viral infections. Cells of the innate immune system (such as NK, macrophages, APC and surface epithelia) express pattern recognition receptors (PRR) which recognise PAMPs and induce an innate immune response. Activation of the innate immune responses induces the expression of pivotal costimulatory molecules (e.g. CD80/B7) on APC which are required for the stimulation of $\mathrm{T}$ cells (Lenschow et al., 1996). The expression of CD80/ B7 by the APC provides information that the antigen is of a non-self origin. Presentation of antigen by APC without the expression of CD80/ $\mathrm{B} 7$ leads to $\mathrm{T}$ cell tolerance to the antigen and is indicative of a response to antigens of self or non-pathogen origin. Activation of the innate immune system induces a milieu of effector cytokines, which also provide the necessary cues for the adaptive immune system.

The Danger Model assumes that what really matters, mattered from an evolutionary point of view, is whether the host is damaged or not. The signals for activation of innate immune response are endogenous in origin so that any cellular distress or unnatural death of a cell leads to the immunomodulatory molecules and cellular effector functions as agents of innate immunity. Thus, the innate immune system derives from tissue responses which are inducible and packaged ready to send signals when damaged. The basic signals 
include molecules which would normally not be found exogenously, including high mannose structures, heat shock proteins, DNA, RNA etc. It is the cells of the innate immune system that have evolved to respond to these danger signals by the production of effector molecules and cellular activity which will eliminate the threat. The innate immune portfolio is localised at epithelial borders and uses many immunoregulatory components. The relevant effector molecules are a variety of cytokines, e.g. interferon (IFN)- $\alpha \beta$, transforming growth factor (TGF)- $\beta$, tumour necrosis factors (TNF), interleukins (IL)-1 and -6, -10, -12, -15, IFN $\gamma$ inducing factor (IGIF) and NK produced IFN $\gamma$ which are all made by cells of the innate immune system. These include monocyte/ macrophages, dendritic and NK cells and some polymorphonuclear leucocytes. However IFN- $\alpha \beta$, TGF $\beta$, TNF, IL-1 and-6 and IGIF can also be made by non-immune cells, reflecting the evolution of cellular injury responses prior to innate immunity. These early events can also lead to the activation of local APC to express costimulatory molecules such as CD80/B7 (Matzinger, 1998). The Danger Model offers the possibility that an infection by a foreign entity which does no injury will not evoke a response. This situation may be highly relevant to an HPV infection in the cervix.

The link between the innate immune system and the adaptive immune system appears to be the endogenous alarm signals ability to activate antigen presenting cells to offer co-stimulatory molecules which are obligate for antigen specific responses. The dendritic cell (DC) is pivotal in the activation of $\mathrm{T}$ cells to become effector cells by providing the necessary second signals through a set of ligand-receptor pairs on the antigen presenting cell and the $\mathrm{T}$ cell, in addition to recognition of the MHC-peptide complex delivered through the specific $\mathrm{T}$ cell receptor (signal 1). The first step in the activation process for DC derives from the local microenvironment (pathogen induced/ derived or constitutively produced tissue factors) when encountering a specific damage/danger. Following DC maturation and differentiation with presentation of processed antigen and acquisition of costimulatory potential, there is a polarization of the $\mathrm{T}$ helper type of response selected in the draining lymph node (LN). Thus the development of naïve $\mathrm{T}$ helper cells under influence of IL-12 yields a $\mathrm{T}$ helper type 1 cytokine profile (TNF, IFN $\gamma$, IL-2) leading to generation of CTL and activated NK cells, whereas IL-10 drives a T helper type 2 (IL-4, IL-5 cytokines) favouring B cell activation and isotype switching etc. These $\mathrm{T}$ cell subset generations are biased by the first experiences of the DC (Kalinski et al., 1999). HPV may be exploiting the endogenous tissue responses utilised by innate immunity to skew the adaptive immune response away from a more threatening Th1 response.

DC can discriminate between tissues that are damaged by stress or infection and those undergoing tissue remodelling as a normal process (Galluci et al., 1999). The early premalignant life history of the papillomavirus may occur in the absence of any damage and cell loss will be by normal tissue homeostasis and principally apoptosis. If unstimulated DC operate to capture apoptotic cells and present the captured antigens, without costimulation this may induce tolerance in autoreactive or virus antigen specific $\mathrm{T}$ cells.

\section{The immune response in HPV associated disease: reality}

Unfortunately, in spite of the wealth of understanding of the functioning immune response, there are great limitations to our knowledge of the natural control of HPV infections in the cervix. However, circumstantial evidence suggests a role for both the serological and cellular immune system in the clearance of HPV infections. Thus immune recognition of viral products is prevalent on exposure to the virus and immune suppression increases the frequency of HPV associated lesions. The difficulty is ascribing the measured immunological output to any particular clinical consequence. The measurement of immunological parameters which are accessible, but not necessarily pivotal in the disease process, in groups of women which have undefinable HPV natural lifetime history makes interpretation extremely difficult. The very nature of adaptive immunity involves memory which may persist without evi- 
dence of continuing infection or be maintained by frequent re-exposure but otherwise be inherently short-lived.

\section{Local immune responses}

HPV infections are not systemic, remaining at the site of initial infection. Therefore, the first line of defence would be at the mucosal surface via the innate immune system. Some insight into these early events may be derived from studies of regression of genital warts which is associated with an increase in infiltration of macrophages, NK and CD4 + T cells (Coleman et al., 1994). Responders to treatment of warts with IFN $\gamma$ and IFN $\alpha 2$ a showed a marked increase in infiltrating Th1 inflammatory cells, macrophages and NK cells with the activated CD4 + showing a proliferative response to HPV6/11 L1. Only $15 \%$ of responder patients had lesions with infiltrating lymphocytes, which proliferated in response to HPV6/11 E7 despite proliferative responses being detected in the peripheral blood. Non responders were shown to be depleted of Langerhans Cells (LC) with less $\mathrm{T}$ cell infiltration and reduced levels of IL-1, GM-CSF and TNF. Non responders also showed high levels of E7 expression. (Arany and Tyring, 1996; Hong et al., 1997). These results suggest that the key events in lesion destruction depend on a Th1 response, which does not necessarily target the E7 gene product. This is generally supported by Th1 cytokine patterns in CIN lesions which are subsequently cleared (Scott et al., 1999) or progression of CIN associated with a Th2 immunodeviation (al-Saleh et al., 1998)

One strategy used by the viruses to evade the consquences of IFN $\alpha$ has been demonstrated by Barnard and McMillan (1999). They reported that HPV16 E7 can inhibit the induction of IFN- $\alpha$ inducible genes but not IFN- $\gamma$ inducible genes. This is consistent with observations by Schneider et al. (1987) who reported that HPV16 and 18 lesions show a reduced response to IFN $\alpha$ treatment in comparison to HPV6 and 11 lesions. Furthermore, HPV16 or 18 lesion responders to IFN $\alpha$ showed reduced levels of E7 in comparison to non-responders. Therefore, high risk HPV le- sions may be relatively refractory to host innate immune responses compared to low risk type infections. Li et al. (1999) have also demonstrated the HPV18 E6 binds to Tyk2 and so prevents Tyk 2 from binding to the IFN $\alpha$ receptor 1 . This leads to the breakdown of the IFN $\alpha$ Jak-STAT pathway. The binding of E6 to Tyk2 is viral type dependent, with the HPV18 E6 binding stronger than the E6 from HPV6. This suggests that the reason that lesions due to low risk HPV infections are more susceptible to IFN $\alpha$ than the high risk HPV lesions is due to the poor ability of the HPV6 E6 to interfere with the Jak-STAT pathway. Thus persistent high risk HPV infection may result, at least in part, from the viral oncogene mediated protection from interferons induced by innate immunity.

Alternatively, any interference with local APC of the cervix may protect the infected tissue from the attentions of the host immunity. A recent analysis showed that the number of LCs (immature epidermal dendritic cells) was significantly reduced in dysplasia or HPV infection, using the S-100 protein marker but not the CD1 antigen (Connor et al., 1999). The relative absence of the S100 protein expressing LC subpopulation may be a reflection of early failure of endogenous activation events influenced by viral gene expression. Others have also shown lack of activation of LC in cervix lesions together with downregulation of the cytokine $\mathrm{TNF} \alpha$ produced by basal keratinocytes and up-regulation of the suppressive cytokine IL-10 in CIN compared with normal cervix epithelium (Mota et al., 1999). All these influences in the HPV infected tissue may serve to bias any adaptive immunity towards a Th2 rather than a Th1 type response. Is it possible that the evolution of HPV has produced a pathogen which survives by a combination of stealth, specific interferences with innate immunity with knock on effects on adaptive immunity which in themselves becomes advantageous for the infection?

\section{Antigen specific responses}

The goal of both the prophylactic or therapeutic immunisation is the stimulation of the adaptive 
immune response (with memory) to produce antigen specific effector molecules and/or cells to either prevent infection or eliminate infected or transformed cells. The target of choice for prophylaxis is the viral particle composed of the capsid proteins L1 and L2, whereas the viral oncogenes E6 and E7 are considered the appropriate therapeutic targets because they are expressed through all stages of cervical neoplasia. Other viral products like E2 controlling both viral replication and transcription may also be respectable immune targets for vaccines aimed at premalignant lesion prevention and/or therapy. In contrast to the late proteins which are expressed only in teminally differentiated epithelial cells, E2 is required in the first events associated with viral infection and therefore would allow immune targeting across the HPV life cycle. The knowledge of such adaptive immunity to these HPV antigens in the natural history of cervical neoplasia is limited by the difficulties of measuring specific immunity, which is important locally, with sampling from the peripheral blood. The choice of immunisation schedule and immune assays also reflects prejudices about the chosen targets and types of response required. There is no precise understanding of the interactions between the innate and adaptive immune systems and what nonspecific or specific immune processes deliver HPV lesion resolution. This does not mean that the various vaccine strategies in progress will not work but we frequently have no direct evidence that they will succeed, as presumably must occur in the vast majority of natural infections that show no clinical manifestation.

In terms of prophylactic vaccines, the generation of neutralising antibodies with virus-like particles (VLP) against the viral particles is seen as the goal. Support for this derives from numerous studies showing protection against animal papillomavirus infection associated with antibodies recognizing conformational epitopes on virus-like particles used as immunogens; these antibodies are also able to neutralize the animal viruses (Schiller, 1999). The serological response to HPV capsid proteins is undoubtedly a consequence of exposure to the pathogen but absence of such antibodies does not necessarily mean lack of in- fection. Thus, a recent Swedish study detected HPV 16 capsid type specific antibodies in 33, 55 and $72 \%$ of adult women who were HPV negative, HPV infected healthy or with CIN respectively (af-Geijersstam et al., 1999). HPV infection in sexually active women usually results in an asymptomatic infection which often clears; only a minority develop high grade lesions (Kotloff et al., 1998). Depression of the humoral immune system does not result in an increase in the HPV lesions and so it is unlikely that antibodies alone are capable of viral clearance (Lutzner, 1985). However, there is an increase in the frequency of HPV lesions in individuals with depressed cell mediated immunity such as HIV infection (Garzetti et al., 1994; Petry et al., 1994) and allograft transplant patients (Ozsaran et al., 1999). These immunological defects may also have consequences for innate responses which play an inherent part in overall control of HPV infections in the cervix.

Serological assays using virus-like particles (VLPs) indicate that a high proportion of individuals exposed to HPV with and without cervical lesions develop systemic antibodies to L1 (Kirnbauer et al., 1996; Carter et al., 1996; Lehtinen et al., 1996; De Gruijl et al., 1997). In addition, IgA antibodies against capsid proteins are found in the cervical secretions (Wang et al., 1996) but these may not correlate with lesion clearance (Bontkes et al., 1999). These Th-dependent antibody responses generally do not predict HPV clearance, but not all conformational-dependent antibodies are necessarily neutralising, therefore, the pattern of L1 antibodies detected may not correlate with efficacy of HPV protection (Leiserowitz et al., 1997).

Neutralising antibodies may be an effective way of preventing viral infection and spread, but cellmediated surveillance of virally infected cells may also be important in the ultimate resolution of infection and disease. It might be expected that effective $\mathrm{T}$ helper responses to $\mathrm{L} 1$ would emerge at the early stages of infection, when late protein synthesis occurs as part of the production of infectious virions. $\mathrm{T}$ helper responses to $\mathrm{L} 1$ presented as peptides or as VLPs have been detected in vitro by proliferation and IL-2 release assays 
respectively, in CIN patients as well as controls, but responses are not found more frequently in patients with low grade lesions (Shepherd et al., 1996; De Gruijl et al., 1999). In contrast patients with persistent HPV16 infections with CIN III, as well as with cancer showed a higher frequency of specific E7 $\mathrm{T}$ cell activity as measured by IL-2 release although there was evidence of responses diminishing from the putative infection point in lesion clearance patients (De Gruijl et al., 1998). Others have reported a correlation of E7 peptide induced proliferation with HPV DNA clearance (Kadish et al., 1996). Th1 responses to HPV 16 E2 have also been detected in HPV 16 positive patients. Longitudinal studies show that Th responses to the $\mathrm{C}$ terminal of E2 occurred at the time of viral clearance although it was not possible to determine the actual role of the anti-E2 response in clearance (Bontkes et al., 1999). Taken together it would appear that in some HPV infections, the host can mount a Th1 response, which may include E7 and E2 as targets and which contribute to viral clearance. However it is clear that in a significant proportion of patients with persistent CIN or carcinoma, HPV 16 E7 T cell responses do not resolve the lesions; this may reflect immune escape mechanisms acting at the effector (Rudolf et al., 2000) or target levels (Garrido et al., 2000). The most popular candidate effector cell is the cytotoxic T lymphocyte (CTL) and vaccine strategies aimed at boosting this type of response are in progress (Borysiewicz et al., 1996). However CTLs to the HPV E7 are difficult to detect in peripheral blood in patients known to have been exposed to HPV16/18 (Borysiewicz et al., 1996; Ressing et al., 1996; Nimako et al., 1997) but can be apparently be detected at a higher frequency in tumour infiltrating lymphocytes (Evans et al., 1997). CTLs recgonize a complex of HLA class 1 molecules and peptides so those present in patients or generated as a result of vaccination versus HPV oncogenes may be impotent because of the frequency of HLA class I downregulation seen in cervical neoplasia. This occurs in CIN lesions as well as cervix cancers and can be associated with progression (Bontkes et al., 1998). Recent detailed molecular analyses of cervical carcinomas have shown that these HLA class I dysregulations result from multiple genetic mechanisms and occur in around $90 \%$ of tumours (Brady et al., 2000; Koopman et al., 2000).

\section{Vaccine design and testing}

Several potentially prophylactic vaccines based on HPV 16 L1 VLPs have entered Phase 1 clinical trials and preliminary evidence suggests they are safe and immunogenic, eliciting capsid specific antibodies which are capable of neutralising virus (Schiller, personal communication). However, from our limited knowledge of natural immunity to HPV it seems unlikely that just a humoral response to viral capsid proteins would provide a complete protection from viral challenge. While humoral immunity may significantly reduce the infection rate it will not provide sterilising immunity such that any HPV viral particle would be neutralised prior to infection. Thus if infections occur, for example if the antibody 'barrier' is not maintained at a protective level throughout the hosts lifetime, then a viral integration could lead to the generation of a malignant cell phenotype for which humoral immunity versus capsid proteins would be irrelevant. Additional cellular immunity which can act directly on virally infected cells will also be required and we have little understanding of the necessary and sufficient components of this in natural infection.

The recent demonstration of CTL responses to E7 proteins and other antigens presented as chimaeric VLPs offers some attractive new approaches in the development of second generation vaccines (Muller et al., 1997; Greenstone et al., 1998; Peng et al., 1998; Schafer et al., 1999; Rudolf et al., 1999). This type of immunisation could use HPV target antigens to cover both prophylactic and therapeutic options. A maximally effective vaccination/immunisation might be delivered by a VLP chimaeric fusion generating a humoral response to viral capsids for managing any viral load and preventing further infection at the cervix together with a CTL response versus HPV early genes (E7 and/or E6 and/or E2) for eliminating the infected cells. The chimaeric VLPs 
appear to induce CTL responses in the absence of adjuvant so these vaccines may not require such formulation. The generation of appropriate local immunity, ease of vaccination and longevity of memory are all critical issues in effective vaccination and route of immunisation may be an important key in influencing these factors. Delivery of antigens by subcutaneous immunisation results in the generation of systemic humoral immune responses which may not play a role in the prevention of viral infection locally but could nevertheless be an important indicator of the potential for clearance of the virus from lesions in the cervix (Bontkes et al., 1991). Systemic immunization with VLPs in African green monkeys has also shown the elicitation of significant levels of HPV neutralising antibodies in cervicovaginal secretions (Lowe et al., 1997). The demonstration that nasal immunisation with virus-like particles in mice can induce neutralising antibodies throughout the estrous cycle (Nardelli-Haefliger et al., 1999) and also activate specific CD4 and CD8 T cells in the vagina (Dupuy et al., 1999) suggests that vaccination protocols to elicit mucosal immunity will be advantageous for prophylaxis. Measuring such local responses in patient trials is not easy but it will be important to monitor both systemic and local antibody and cell mediated responses where possible.

In cervical neoplasia there are many problems in clinical trial design for either prophylactic or therapeutic vaccination protocols. For prophylactic vaccination, the natural endpoint showing a failure of the protocol would be the generation of a HPV lesion. This would require the lengthy follow up of individuals since it has been calculated that the time between infection and the generation of a detectable CIN lesion may be at least 6 years (Melkert et al., 1993; de Roda Husman et al., 1995). The age of the individuals within any prophylactic trial is also important since although younger women are more likely to become HPV positive and have a greater risk of generating an HPV associated lesion (Melkert et al., 1993; de Roda Husman et al., 1995), they are also more likely to show regression of CIN lesions (van Oortmarssen et al., 1992). The generation of complete protection from infection may be unobtainable but even if possible it will be an long time before any abandonment of screening pro- grammes for prophylaxis and is certainly not a realistic goal for the foreseeable future.

Measurement of the effectiveness of a therapeutic vaccine for CIN also has several problems to overcome. Since it will be used as adjuvant treatment post removal of the initial lesion by conventional methods (since it would be unethical to allow a detected lesion to progress to cancer), the background of the original treatment may mask any effect of the vaccine. This is also hampered by the fact that the rate of recurrence of HPV lesions after treatment is very low ( $10 \%$ over 10 years) requiring extremely large cohorts of women in long-term follow up studies (Luesley et al., 1990; Flannelly et al., 1997). A therapeutic effect of TA-HPV, a live recombinant virus expressing the human papillomavirus 16 and 18 E6 and E7 proteins is being monitored in patients with early cervical cancer but at least 5 years of follow-up will be required to see any clinical influence because of the overall good prognosis for this group of patients.

To really drive forward the large-scale implementation of vaccination programmes it will be necessary to design clinical trials for the various current or the next generation of HPV vaccines to deliver unequivocal evidence of benefit from immunisation. This is best addressed by looking for effects on prevalent infections. The demonstration that HPV L1 and related vaccinations can influence the disease course in patients with current HPV infections would allow the vaccines to be used therapeutically in patients who are already determined to be at risk (presence of high risk HPV). A potential model for such HPV vaccine trials would be the development of agents acting against vulval intraepithelial neoplasia (VIN).

The majority of VIN results from high risk HPV 16 infection that is maintained episomally within the lesion. The detection of HPV positive VIN in younger women has increased dramatically over the last 20 years (Jones et al., 1997). The multifocal presentation and uncertain risk of progression to malignant disease makes it a difficult disease to treat, with a high $(50 \%)$ recurrence rate (Jones and Rowan, 1994). VIN is particularly resistant to treatment, often requiring surgical excision, which can be mutilating, especially when repeated (Herod et al., 1996). Previous clinical data have shown that 
a vaccinia HPV oncogene vaccine (TA-HPV) is capable of producing an immunological response with evidence of a B-cell reaction and, perhaps more importantly, a specific cytotoxic T-cell response, even in patients with advanced HPV-related disease (Borysiewicz et al., 1996). This approach is now to be further studied in women with VIN3 in a clinical trial centred in Manchester, UK. As well as studying the safety, tolerability and immunogenicity of the vaccination, the trial design can provide for evidence of clinical efficacy by comparing the extent of VIN3 and HPV status of the lesions before and after TA-HPV vaccination.

It seems reasonable to consider VIN for clinical trial of HPV VLP vaccines. Our recent studies suggest that the immune response is controlling the VIN lesions without eliminating them and that immune escape is a feature of progression of the lesions to vulval cancer (Abdel-Hady et al., 2000 Adel-Hady et al in preparation). We have shown that high- risk HPV 16 infection is frequent in VIN and is associated with a poorer response to photodynamic therapy (PDT). Immunological, factors also appear to be important since infiltrating CD8 $\mathrm{T}$ lymphocytes appear to be associated with an effective response of VIN to PDT and complete loss of HLA class I expression is common in vulval carcinoma and may be an early event in the progression of VIN to micro-invasion. These observations suggest that combinations of PDT and immunotherapy directed at HPV target antigens may yield longer- term resolution of persistent VIN. A chimaeric vaccine directed against both HPV 16 capsid and early gene proteins which may be biased towards a Th1 type response, may be capable of delivering a higher frequency of long term lesion resolution in this patient population. The attractiveness of such a trial would be the possible synergistic influences of the PDT and the vaccine with a clear measurable clinical outcome.

\section{References}

Abdel-Hady ES, Martin-Hirsch P, Duggan-Keen M, Stern PL, Moore, JM. HLA expression, HPV infection and the response of vulval intraepithelial neoplasia to photodynamic therapy. Lancet 2000, submitted.
af-Geijersstam V, Eklund C, Wang Z, Sapp M, Schiller JT, Dillner J, Dillner L. A survey of seroprevalence of human papillomavirus types 16, 18 and 33 among children. Int J Cancer 1999;80:489-93.

al-Saleh W, Giannini SL, Jacobs N, Moutschen M, Doyen J, Boniver J, Delvenne P. Correlation of T-helper secretory differentiation and types of antigen-presenting cells in squamous intraepithelial lesions of the uterine cervix. J Pathol 1998;184:283-90.

Arany I, Tyring SK. Status of local cellular immunity in interferon-responsive and -non-responsive human papillomavirus-associated lesions. Sex Transm Dis 1996;23:475-80.

Barnard P, McMillan NA. The human papillomavirus E7 oncoprotein abrogates signaling mediated by interferon-alpha. Virology 1999;259:305-13.

Bontkes HJ, Walboomers JMM, Meijer CJLM, Helmerhorst TJM, Stern PL. Specific HLA class I down-regulation is an early event in cervical dysplasia associated with clinical progression. Lancet 1998; 351, 187-188.

Bontkes HJ, de Gruijl TD, Walboomers JM, Schiller JT, Dillner J, Helmerhorst TJ, Verheijen RH, Scheper RJ, Meijer CJ. Immune responses against human papillomavirus (HPV) type 16 virus-like particles in a cohort study of women with cervical intraepithelial neoplasia. II. Systemic but not local IgA responses correlate with clearance HPV-16. J Gen Virol 1991;80:409-17.

Bontkes HJ, de Gruijl TD, Bijl A, Verheijen RH, Meijer CJ, Scheper RJ, Stern PL, Burns JE, Maitland NJ, Walboomers JM. Human papillomavirus type 16 E2-specific T-helper lymphocytes responses in patients with cervical intraepithelial neoplasia. J Gen Virol 1999;80:2453-9.

Borysiewicz LK, Fiander A, Nimako M, et al. A recombinant vaccinia virus encoding human papillomavirus types 16 and 18, E6 and E7 proteins as immunotherapy for cervical cancer. Lancet 1996;347:1523-7.

Brady CS, Bartholomew JS, Burt. DJ, Duggan-Keen, MF, Glenville S, Telford N, Little, AM, Davison, J, Jimenez, P, Ruiz-Cabello, F, Garrido, F and Stern, PL, Multiple mechanisms underly HLA dysregulation in cervical cancer. Tissue Antige. 2000;55:401-11.

Carter JJ, Koutsky LA, Wipf GC, Christensen ND, Lee SK, Kuypers J, Kiviat N, Galloway DA. The natural history of human papillomavirus type-16 capsid antibodies among a cohort of university women. J Infect Dis 1996;174:927-36.

Coleman N, Birley HDL, Renton AM, Hanna NF, Ryait BK, Byrne M, Taylor Robinson D, Stanley MA. Immunological events in regressing genital warts. Am J Clin Pathol 1994; 102:768-74.

Connor JP, Ferrer K, Kane JP, Goldberg JM. Evaluation of Langerhans cells in the cervical epithelium of women with cervical intraepithelial neoplasia. Gynecol Oncol 1999;75(1):130-5.

De Gruijl TD, Bontkes HJ, Stukart MJ, Walboomers JMM, Schiller JT, Groot BS, Chaboud MR, Remmink AJ, Verheijen RHM, Helmerhorst TJM, Meijer CJLM, Scheper RJ. Immunoglobulin $\mathrm{G}$ responses against human papillomavirus type 16 virus-like particles in a prospective nonintervention cohort study of women with cervical intraepithelial neoplasia. J Natl Cancer Inst 1997;89:630-8. 
De Gruijl TD, Bontkes HJ, Walboomers JMM, Stukart MJ, Doekhie FS, Remmink AJ, Helmerhorst TJM, Verheijen RHM, Duggan-Keen MF, Stern PL, Meijer CJLM, Scheper RJ. Differential T helper responses to human papillomavirus type $16 \mathrm{E} 7$ related to viral clearance or persistence in patients with cervical intraepithelial neoplasia. Cancer Res 1998;58:1700-6.

DeGruijl TD, Bontkes HJ, Walboomers JMM, Coursaget P, Stukart MJ, Dupuy C, Kueter E, Verheijen RHM, Helmerhorst TJM, Verheijen RHM, Helmerhorst TJM, DugganKeen MF, Stevens FRA, Dyer PA, Stern PL, Meijer CJLM, Scheper RJ. Differential Th and IgG responses to HPV-16 L1 containing virus-like particles in relation to cervical intraepithelial neoplasia and HLA genotype. J Gen Virol 1999;80:399-408.

de Roda Husman AM, Walboomers JM, van den Brule AJ, Meijer CJ, Snijders PJ. The use of general primers GP5 and GP6 elongated at their 3' ends with adjacent highly conserved sequences improves human papillomavirus detection by PCR. J Gen Virol 1995;76:1057-62.

Duggan MA, McGregor SE, Stuart GC, Morris S, Chang-Poon V, Schepansky A, Honore L. The natural history of CIN I lesions. Eur J Gynaecol Oncol 1998;19:338-44.

Duggan-Keen MF, Brown MD, Stacey SN, Stern PL. Papillomavirus vaccines. Front BioSci 1998;3:192-1208.

Dupuy C, Buzoni-Gatel D, Touze A, Bout D, Coursaget P. Nasal immunization of mice with human papillomavirus type 16 (HPV-16) virus-like particles or with the HPV-16 L1 gene elicits specific cytotoxic $\mathrm{T}$ lymphocytes in vaginal draining lymph nodes. J Virol 1999;73:9063-71.

Evans EML, Man S, Evans AS, Borysiewicz LK. Infiltration of cervical cancer tissue with human papillomavirus specific cytotoxic T lymphocytes. Cancer Res 1997;158:2943-50.

Flannelly G, Langhan H, Jandial L, Mana E, Campbell M, Kitchener H. A study of treatment failures following large loop excision of the transformation zone for the treatment of cervical intraepithelial neoplasia. Br J Obstet Gynaecol 1997; 104:718-22.

Galluci S, Lolkema M, Matzinger P. Natural adjuvants: endogenous activators of dendritic cells. Nat Med 1999;5:1249-55.

Garrido F, Cabrera T, Steen PL. HLA and Cancer. In: Ochoa (Ed.) Tumor Escape Mechanisms, Academic Publishers, 2000 (in press).

Garzetti GG, Ciavattini A, Buttini L, Vecchi A, Montroni M. Cervical dysplasia in HIV-seropositive women - role of human papillomavirus infection and immune status. Gynecol Obstet Invest 1994;40:52-6.

Greenstone HL, Nieland JD, deVisser KE, DeBruijn MLH, Kirnbauer R, Roden RBS, Lowy DR, Kast WM, Schiller JR. Chimeric papillomavirus virus-like particles elicit antitumour immunity against the E7 oncoprotein in an HPV16 tumour model. Proc Natl Acad Sci USA 1998;95:1800-5.

Herod JJ, Shafi MI, Rollason TP, Jordan JA, Luesley DM. Vulvar intraepithelial neoplasia. Long-term follow-up of treated and untreated women. $\mathrm{Br} \mathrm{J}$ Obstet Gynaecol 1996;103:446-52.
Ho GY, Burk RD, Klein S, Kadish AS, Chang CJ, Palan P, Basu J, Tachezy R, Lewis R, Romney S. Persistent genital human papillomavirus infection as a risk factor for persistent cervical dysplasia. J Natl Cancer Inst 1995;87:1365-71.

Hong K, Greer CE, Ketter N, Van-Nest G, Paliard X. Isolation and characterization of human papillomavirus type 6-specific T cells infiltrating genital warts. J Virol 1997;71:642732.

Janeway CA. The immune system evolved to discriminate infectious nonself form noninfectious self. Immunol Today 1992;13:11-6.

Jones RW, Rowan DM. Vulvar intraepithelial neoplasia III: a clinical study of the outcome of 113 cases with relation to the later development of invasive vulvar carcinoma. Obstet Gynecol 1994;84:741-5.

Jones RW, Baranyai J, Stables S. Trends in squamous cell carcinoma of the vulva: the influence of vulvar neoplasia. Obstet Gynecol 1997;90:448-53.

Kadish AS, Ho GYF, Burk RD, Wang YX, Romney SL, Ledwidge R, Angeletti RH. Lymphoproliferative responses to human papillomavirus (HPV) type 16 proteins E6 and E7: outcome of HPV infection and associated neoplasia. J Natl Cancer Inst 1996;89:1285-93.

Kalinski P, Hilkens CMU, Wierenga EA, Kapsenberg ML. T-cell priming by type- 1 and type-2 polarized dendritic cells: the concept of a third signal. Immunol Today 1999;20:5617.

Kirnbauer R, Chandrachaud LM, O’Neill BW, Grindlay GJ, Armstrong A, McGarvie GM, Schiller JT, Lowy DR, Campo MS. Virus-like particles of bovine papillomavirus type 4 in prophylactic and therapeutic immunisation. Virology 1996;219:37-44.

Koopman LA, Corver WE, van Der Slik AR, Giphart MJ, Fleuren GJ. Multiple genetic alterations cause frequent and heterogeneous histocompatibility leukocyte antigen class I loss in cervical cancer. J Exp Med 2000;191:961-76.

Kotloff KL, Wasserman SS, Russ K, Shapiro S, Daniel R, Brown W, Frost A, Tabara SO, Shah K. Detection of genital human papillomavirus and associated cytological abnormalities among college women. Sex Transm Dis 1998;25:24350 .

Lehtinen M, Dillner J, Knekt P, Luostarinen T, Aromaa A, Kirnbauer R, Koskela P, Paavonen J, Peto R, Schiller JT, Hakama M. Serologically diagnosed infection with human papillomavirus type 16 and risk for subsequent development of cervical carcinoma: nested case control study. Br Med J 1996;312:537-9.

Leiserowitz GS, Hall KS, Foster CA, Hitchcock ME, Christensen ND, Heim KM, Smith LH. Detection of serologic neutralizing antibodies against HPV-11 in patients with condyloma acuminata and cervical dysplasia using an in vitro assay. Gynecol Oncol 1997;66:295-9.

Lenschow DJ, Walunas TL, Bluestone JA. CD28/B7 system of T cell costimulation. Annu Rev Immunol 1996;14:233-58.

Li S, Labrecque S, Gauzzi MC, Cuddihy AR, Wong AH, Pellegrini S, Matlashewski GJ, Koromilas AE. The human papilloma virus (HPV)-18 E6 oncoprotein physically associates with Tyk2 and impairs Jak-STAT activation by interferon-alpha. Oncogene 1999;18:5727-37. 
Lowe RS, Brown DR, Bryan JT, Cook JC, George HA, Hofmann KJ, Hurni WM, Joyce JG, Lehman ED, Markus HZ, Neeper MP, Schultz LD, Shaw AR, Jansen KU. Human papillomavirus type 11 (HPV-11) neutralizing antibodies in the serum and genital mucosal secretions of African green monkeys immunized HPV-11 virus-like particles expressed in yeast. J Infect Dis 1997;176:1141-5.

Luesley DM, Cullimore J, Redman CW, Lawton FG, Emens JM, Rollason TP, Williams DR, Buxton EJ. Loop diathermy excision of the cervical transformation zone in patients with abnormal cervical smears. $\mathrm{Br}$ Med J 1990;300:1690-3.

Lutzner MA. Papillomavirus lesions in immunodepression and immunosuppression. Clin Dermatol 1985;3:165-9.

Matzinger P. Tolerance, danger and the extended family. Annu Rev Immunol 1994;12:991-1045.

Matzinger P. An innate sense of danger. Sem Immunol 1998;10:399-415.

Medzhitov R, Janeway CA, Jr. Innate immunity: the virtues of a nonclonal system of recognition. Cell 1997;91:295-8.

Melkert PW, Hopman E, van den Brule AJ, Risse EK, van Diest PJ, Bleker OP, Helmerhorst T, Schipper ME, Meijer CJ, Walboomers JM. Prevalence of HPV in cytomorphologically normal cervical smears, as determined by the polymerase chain reaction, is age-dependent. Int $\mathbf{J}$ Cancer 1993;53:919-23.

Mota F, Rayment N, Chong S, Singer A, Chain B. The antigen-presenting environment in normal and human papillomavirus (HPV)-related premalignant cervical epithelium. Clin Exp Immunol 1999;116:33-40.

Muller M, Zhou J, Red TD, Rittmuller C, Burger A, Gabelsberger J, Braspenning J, Gissmann L. Chimeric papillomavirus-like particles. Virology 1997;234:99-111.

Nardelli-Haefliger D, Roden R, Balmelli C, Potts A, Schiller J, De Grandi P. Mucosal but not parenteral immunization with purified human papillomavirus type 16 virus-like particles induces neutralizing titers of antibodies throughout the estrous cycle of mice. J Virol 1999;73:9609-13.

Nimako M, Fiander A, Wilkinson GWG, Borysiewicz LK, Man S. Human papillomavirus-specific cytotoxic T lymphocytes in patients with cervical intraepithelial neoplasia grade III. Cancer Res 1997;57:4855-61.

Ozsaran AA, Ates T, Dikmen Y, Zeytinoglu A, Terek C, Erhan Y, Ozacar T, Bilgic A. Evaluation of the risk of cervical intraepithelial neoplasia and human papilloma virus infection in renal transplant patients receiving immunosuppressive therapy. Eur J Gynaecol Oncol 1999;20:127-30.

Peng S, Frazer IH, Fernando GJ, Zhou J. Papillomavirus like particles can deliver defined CTL epitopes to the MHC class I pathway. Virology 1998;240:147-57.

Petry KU, Scheffel D, Bode U, Gabrysiak T, Kochel H, Kupsch E, Glaubitz M, Niesert S, Kuhnle H, Schedel I. Cellular immunodeficiency enhances the progression of human papillomavirus-associated cervical lesions. Int $\mathbf{J}$ Cancer 1994;57:836-40.
Remmink AJ, Walboomers JM, Helmerhorst TJ, Voorhorst FJ, Rozendaal L, Risse EK, Meijer CJ, Kenemans P. The presence of persistent high-risk HPV genotypes in dysplastic cervical lesions is associated with progressive disease: natural history up to 36 months. Int $\mathbf{J}$ Cancer 1995;61:306-11.

Ressing ME, van Driel WJ, Celis E, Sette A, Brandt MP, Hartman M, Anholts JD, Schreuder GM, ter Harmsel WB, Fleuren GJ, Trimbos BJ, Kast WM, Melief CJ. Occasional memory cytotoxic $\mathrm{T}$-cell responses of patients with human papillomavirus type 16-positive cervical lesions against a human leukocyte antigen-A *0201-restricted E7-encoded epitope. Cancer Res 1996;56:582-8.

Rudolf MP, Nieland JD, DaSilva DM, Velders MP, Muller M, Greenstone HL, Schiller JT, Kast WM. Induction of HPV16 capsid protein-specific human $\mathrm{T}$ cell responses by virus-like particles. Biol Chem 1999;380:335-40.

Rudolf M.P., Small L.A., Velders M.P., DaSilva D.M., Wejzen S., Kast W.M.@ Vaccine delivery and immunosupression in cervical cancer. In: Stern P.L., Beverley P.C.L., Carroll M.W. (Eds.), Cancer Vaccines and Immunotherapy. Cambridge University Press, 2000; 82-106.

Schafer K, Muller M, Faath S, Henn A, Osen W, Zentgraf H, Benner A, Gissmann L, Jochmus I. Immune response to human papillomavirus 16 L1E7 chimeric virus-like particles: induction of cytotoxic $\mathrm{T}$ cells and specific tumor protection. Int J Cancer 1999;81:881-8.

Schiller JT. Papillomavirus-like particle vaccines for cervical cancer. Mol Med Today 1999;5:209-15.

Schneider A, Papendick U, Gissmann L, De-Villiers EM. Interferon treatment of human genital papillomavirus infection: importance of viral type. Int $\mathbf{J}$ Cancer 1987;40:610-4.

Scott M, Stites DP, Moscicki AB. Th1 cytokine patterns in cervical human papillomavirus infection. Clin Diagn Lab Immunol 1999;6:751-5.

Shepherd PS, Rowe AJ, Cridland JC, Coletart T, Wilson P, Luxton JC. Proliferative T-cell responses to human papillomavirus type-16 L1 peptides in patients with cervical dysplasia, J. Gen. Virol. 1996;77.

Syrjanen KJ. Natural history of genital human hapillomavirus infections. In: Lacey C, editor. Papillomavirus Reviews: Current Research on Papillomaviruses. Leeds: Leeds University Press, 1996:189-206.

Tindle RW. Vaccines for human papillomavirus infection and anogenital disease. R.G. Landes Co., Austin Texas, USA. Medical Intelligence Unit 14.

van Oortmarssen GJ, Habbema JD, van Ballegooijen M. Predicting mortality from cervical cancer after negative smear test results. Br Med J 1992;305:449-51.

Wang ZH, Hansson BG, Forslund O, Dillner L, Sapp M, Schiller JT, Bjerre B, Dillner J. Cervical-mucus antibodies against human papillomavirus type 16 , type 18 , and type 33 capsids in relation to presence of viral DNA. J Clin Microbiol 1996;34:3056-62. 